\title{
Inhibition of Luteinizing Hormone-Releasing Hormone Secretion by $\delta$-Opioid Agonists in GT1-1 Neuronal Cells*
}

\author{
ROBERTO MAGGI, FEDERICA PIMPINELLI, LUCIANO MARTINI, AND FLAVIO PIVA \\ Department of Endocrinology, University of Milan, 20133 Milan, Italy
}

\begin{abstract}
The endogenous opioids play a major role in regulation of the secretion of hypothalamic LHRH. However, it is not clear whether opioids exert a direct effect on LHRH neurons or interfere with other neuronal systems impinging on the cells synthesizing LHRH. The neuronal LHRH-producing cell line GT1 provides a new model to evaluate which signals may directly modify LHRH release. In a previous paper it has been reported that opioid-binding sites of the $\delta$-type are present in a clone of the GT1 cells (GT1-1). In the present study, the possible effects of opioids on the release of LHRH were studied in
\end{abstract}

GT1-1 cells. The results obtained show that only the addition of opioid agonists that bind to $\delta$-receptors brings about a significant inhibition of forskolin- or prostaglandin $\mathrm{E}_{2}$-stimulated LHRH release in GT1-1 cells. The effect of the $\delta$-opioid agonist [D-Pen ${ }^{2}, \mathrm{D}-\mathrm{Pen}^{5}$ ]enkephalin is dose dependent and is reversed by the universal opioid antagonist naltrexone and the $\delta$-specific antagonist naltrindole. No effect of opioid agonists or antagonists was observed in unstimulated cells. These results suggest that opioids may control the release of LHRH also, acting directly on LHRH-producing neurons. (Endocrinology 136: 5177-5181, 1995)
$\mathrm{T}$ HE SECRETION of anterior pituitary gonadotropins is under the control of the hypothalamic hormone LHRH $(1,2)$. The neurons that synthesize LHRH are innervated by multiple nervous pathways, which use different neurotransmitter systems to modify LHRH release and, consequently, to modulate gonadotropin secretion $(2,3)$. The study of the neurons that synthesize LHRH is made difficult by the peculiar anatomy of the LHRH system, which is composed of only a few hundred neurons scattered throughout the hypothalamic area. A promising tool for investigation of the direct effects of the different neurotransmitters, feedback signals, etc. on LHRH release became available recently when an immortalized line of LHRH-producing neurons (the GT1 cells) was developed (4-6). Recently, the receptors for several families of neurotransmitters known to modify LHRH secretion [e.g. those for norepinephrine (7), dopamine (8), $\gamma$-aminobutyric acid (9), excitatory amino acids $(10,11)$, endothelin (12), etc.] have been identified on GT1 cells. The stimulatory or inhibitory activity of the corresponding agonists on LHRH secretion has also been documented $(7-9,11$, 12).

Among the transmitters involved in the control of LHRH release, the endogenous opioid peptides (Met- and Leu-enkephalin, dynorphin, $\beta$-endorphin, etc.) play a relevant role $(1,2,13-15)$. Opioid agonists (e.g. morphine) have been shown to inhibit gonadotropin release, whereas opioid antagonists (e.g. naloxone) stimulate LH output $(2,16,17)$. Little is known about the site where opioids act to modulate go-

Received July 24, 1995

Address all correspondence and requests for reprints to: Dr. Roberto Maggi, Department of Endocrinology, Via G. Balzaretti 9, 20133 Milan, Italy.

* This work was supported by Consiglio Nazionale delle Ricerche (Projects BTBS 93.01103.PF70, FATMA 93.00700PF41, ACRO 94.01162PF39, and Aging 94.00470PF40), Associazione Italiana per la Ricerca sul Cancro, and Ministero dell' Università e della Ricerca Scientifica e Tecnologica. nadotropin secretion. The majority of the in vivo studies available support the view that the effects exerted by the opioids on the LHRH-secreting system might be indirect, via interaction with neuronal systems that impinge on LHRH neurons and influence LHRH secretion through the release of their specific neurotransmitters (2). Because of the problems mentioned above, there is no clear-cut evidence of a direct effect of natural or synthetic opioids on LHRH-producing neurons.

In a preceding paper, Maggi et al. (18) demonstrated that opioid-binding sites of the $\delta$-type are present in intact GT1-1 cells as well as their membrane preparations. These receptors appear to be functional, as treatment of GT1-1 cells with the specific $\delta$-opioid agonist [D-Pen ${ }^{2}, \mathrm{D}-\mathrm{Pen}^{5}$ ]enkephalin (DPDPE) inhibits the intracellular accumulation of cAMP (18). An obvious question arising from these results is whether $\delta$-agonists might also influence the release of LHRH. To this purpose, GT1-1 cells were exposed to different opioid agonists or antagonists both under basal conditions and during exposure to stimuli [forskolin (FSK) and prostaglandins (PGs)] known to release LHRH from this cell line $(12,19)$, and the accumulation of LHRH in the culture medium was measured. The experiments under stimulated conditions were performed because data showed that opioids mainly exert an inhibitory effect on LHRH secretion. Even if the binding studies cited above (18) indicated the presence of $\delta$-binding sites only on GT1-1 cells, we believed it important to also investigate the effects of agonists and antagonists that bind to the other major subclasses of opioid-binding sites ( $\mu$ and к) (20).

\section{Materials and Methods}

\section{Cell cultures}

GT1-1 cells, generously provided by Dr. R. I. Weiner (San Francisco, CA) through Dr. B. Marchetti (Catania, Italy) were routinely grown in monolayer at $37 \mathrm{C}$ in a humidified $\mathrm{CO}_{2}$ incubator in Dulbecco's 
Minimum Essential Medium (DMEM) containing $1 \mathrm{~mm}$ sodium pyruvate, $100 \mu \mathrm{g} / \mathrm{ml}$ streptomycin, $100 \mathrm{U} / \mathrm{ml}$ penicillin, and $10 \mathrm{mg} /$ liter phenol red (Biochrom, Berlin, Germany) and supplemented with 10\% fetal calf serum (GIBCO, Grand Island, NY). The medium was replaced at 2-day intervals. Subconfluent cells were routinely harvested by trypsinization and seeded in $57-\mathrm{cm}^{2}$ dishes $\left(1 \times 10^{6}\right.$ cells) for propagation. For the experiments, GT1-1 cells, within 6 passages, were plated in 24-well plates $\left(0.5 \times 10^{6}\right.$ cells $\left./ \mathrm{cm}^{2}\right)$ and used after 5 days of culture.

\section{Chemicals}

$\left[\mathrm{D}-\mathrm{Ala}^{2}, \mathrm{~N}-\mathrm{Me}-\mathrm{Ph} \mathrm{e}^{4}, \mathrm{Gly}^{5}\right.$-ol]Enkephalin (DAGO), DPDPE, [D-Ala ${ }^{2}, \mathrm{D}-$ Leu ${ }^{5}$ ]enkephalin (DADLE), naltrexone, naltrindole, FSK, PGE 1 , and $\mathrm{PGE}_{2}$ were obtained from Sigma Chemical Co. (St. Louis, MO); trans( \pm )-3,4-dichloro- $N$-methyl- $N$-[2-(1-pyrrolidinyl)cycloexyl]-benzen-acetamide methane sulfonate (U-50488H) was kindly provided by Upjohn Co. (Kalamazoo, MI).

\section{Experimental procedures}

GT1-1 cells were washed with $1 \mathrm{ml}$ DMEM (warmed at $37 \mathrm{C}$ ) and when not otherwise specified, incubated for $30 \mathrm{~min}$ in DMEM containing the substances to be tested. At the end of the incubation period, the medium was collected and centrifuged for $5 \mathrm{~min}$ at 12,000 rpm, and the supernatant was stored at $-70 \mathrm{C}$ until the LHRH RIA. The cells remaining in the culture wells were collected in $0.2 \mathrm{~N} \mathrm{NaOH}$ and assayed for protein content using a microassay (21) with human serum albumin as a standard. No variations in total protein per well were detected in the experimental groups (data not shown).

\section{LHRH RIA}

The LHRH content of culture media was determined by RIA using a commercial antibody (code L-8391, Sigma) and iodinated LHRH (Amersham, Milan, Italy). Synthetic LHRH (NovaBiochem, Laufefingen, Switzerland) was used as standard. All samples from the same experiment were run in duplicate in the same assay. Inter and intraassay variations were $9.4 \%$ and $6.6 \%$, respectively. The sensitivity of the assay was $3.9 \mathrm{pg} / \mathrm{ml}$.

\section{Statistical analysis}

The results were analyzed by analysis of variance and adequate post-hoc tests (Student's $t$ test and Dunnett's test). The dose-response curves were analyzed by means of a Macintosh version of the program ALLFIT (22) kindly provided by Dr. V. Guardabasso (Cyanamid, Catania, Italy).

\section{Results}

In a series of preliminary experiments, it was found that 30-min treatment of GT1-1 cells with 1- $\mu \mathrm{M}$ concentrations of opioid agonists that selectively bind to the $\mu$-receptor (DAGO), the $\delta$-receptor (DPDPE), or the $\kappa$-receptor (U50488H) did not affect the basal release of LHRH in the medium (Table 1). Treatment of GT1-1 cells with the universal opioid antagonist naltrexone was also unable to modify the levels of LHRH measured in the culture medium (Table 1). In a subsequent series of experiments, GT1-1 cells were exposed to FSK (a potent activator of adenylyl cyclase), $\mathrm{PGE}_{2}$, or $\mathrm{PGE}_{1}$ to increase LHRH output. GT1-1 cells treated with FSK show a dose- and time-dependent increase in the accumulation of LHRH in the culture medium (Fig. 1). To further study the effects of the opioids, it was decided to use a submaximal stimulation of LHRH secretion, i.e. a 5- $\mu \mathrm{M}$ concentration of FSK and a 30-min incubation time.

The effects of simultaneous treatment of GT1-1 cells with
TABLE 1. Effects of several opioid agonists and the opioid antagonist naltrexone on basal release of LHRH from GT1-1 cells

\begin{tabular}{lc}
\hline Treatment & LHRH $(\mathrm{pg} /$ well $)$ \\
\hline Control & $91.5 \pm 5.4$ \\
DAGO & $95.4 \pm 6.3$ \\
DPDPE & $81.8 \pm 5.3$ \\
U50488H & $94.3 \pm 7.2$ \\
Naltrexone & $102.4 \pm 7.8$ \\
\hline
\end{tabular}

Cells were incubated with different opioid agonists $(1 \mu \mathrm{M})$ that selectively bind to respectively the $\mu$-receptor (DAGO), $\delta$-receptor (DPDPE), and $\kappa$-receptor (U50488H) or with the opioid antagonist naltrexone. Data represent the mean \pm SEM of sextuplicate samples.
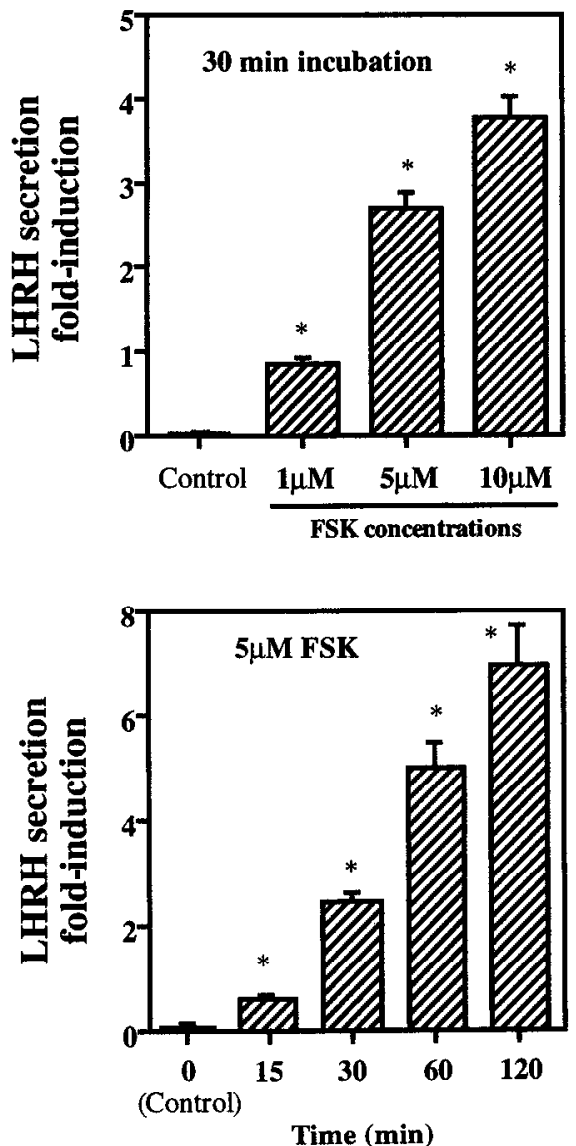

FIG. 1. Dose- and time-related effect of FSK on the release of LHRH from GT1-1 cells. Data represent the mean \pm SEM of sextuplicate samples. ${ }^{*}, P<0.05$ us. control.

FSK and several opioid agonists (in 1- $\mu \mathrm{M}$ concentrations) are presented in Fig. 2. It was evident that the specific $\delta$-opioid agonist DPDPE was able to significantly decrease $(36 \%)$ the LHRH stimulatory effect exerted by FSK. Also, DADLE (a $\delta$-agonist with some intrinsic $\mu$-activity) inhibited FSK-stimulated LHRH release. On the contrary, morphine, the specific $\mu$-agonist DAGO, and the specific $\kappa$-agonist $\mathrm{U} 50488 \mathrm{H}$ were devoid of any significant effect on FSK-induced LHRH release (Fig. 2). The inhibitory effect of DPDPE on FSK-stimulated GT1-1 cells was further investigated using different concentrations of the opioid agonist ranging from $0.1 \mathrm{nM}$ to $1 \mu \mathrm{M}$. The results obtained may be described by a dose- 


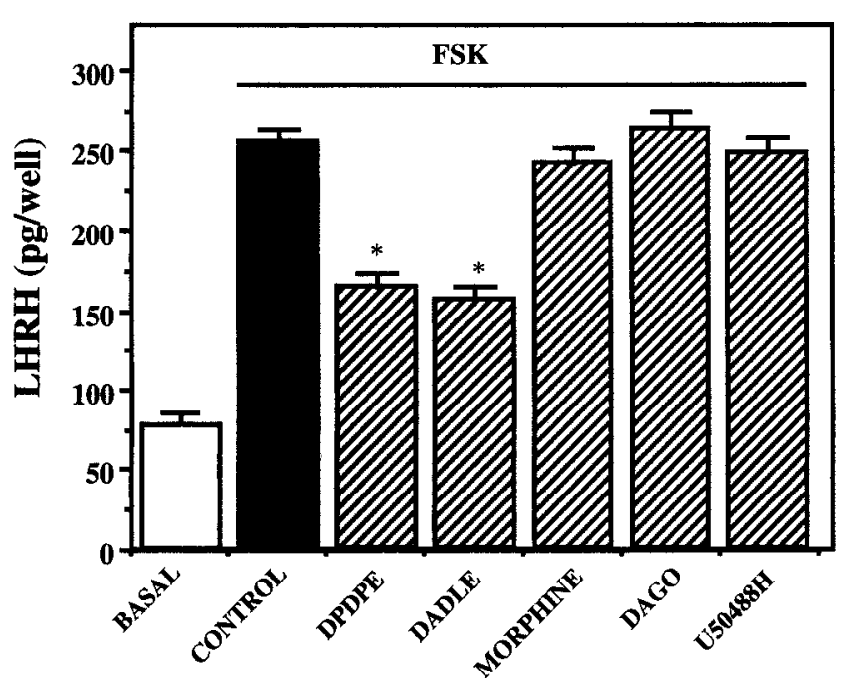

FIG. 2. Effects of opioid agonists on FSK-stimulated secretion of LHRH from GT1-1 cells. Cells were cultured with FSK $(5 \mu \mathrm{M})$ alone (CONTROL) or in combination with $1 \mu \mathrm{M}$ of the different opioids. Data represent the mean \pm SEM of sextuplicate samples. ${ }^{*}, P<0.05$ vs. control.

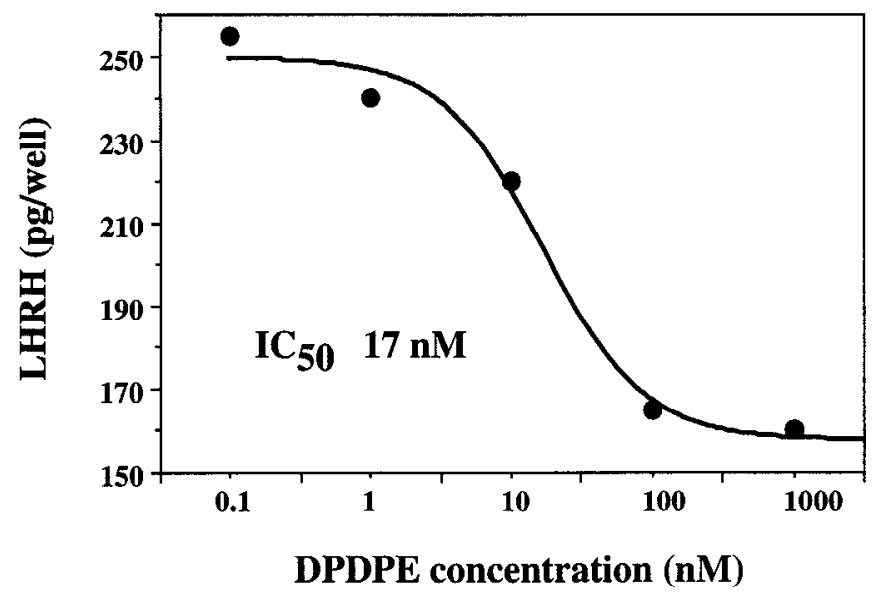

FIG. 3. Dose-response curve of DPDPE on the FSK-stimulated release of LHRH from GT1-1 cells. Cells were incubated with FSK (5 $\mu \mathrm{M})$ in combination with graded concentrations of the opioid agonist. The $\mathrm{IC}_{50}$ value was determined by ALLFIT analysis.

response curve showing an $\mathrm{IC}_{50}$ value of $17 \mathrm{~nm}$ and a slope close to unity (Fig. 3).

Figure 4 shows that treatment of GT1-1 cells for $30 \mathrm{~min}$ with either the universal opioid antagonist naltrexone or the specific $\delta$-antagonist naltrindole did not alter FSK-stimulated LHRH secretion. However, both antagonists fully eliminated the inhibitory effect on LHRH secretion exerted by the $\delta$-agonist DPDPE (Fig. 4).

The effect of DPDPE was also tested on the LHRH release from GT1-1 cells induced by PGs. Table 2 shows that both $\mathrm{PGE}_{2}$ and $\mathrm{PGE}_{1}$ induced a sustained release of LHRH by GT1-1 cells. DPDPE was able to induce a $20-25 \%$ decrease in LHRH release induced by either $\mathrm{PGE}_{2}$ or $\mathrm{PGE}_{1}$ (Table 2).

\section{Discussion}

The present study shows that DPDPE, an agonist selective for the $\delta$-subclass of opioid receptors, inhibits the secretion

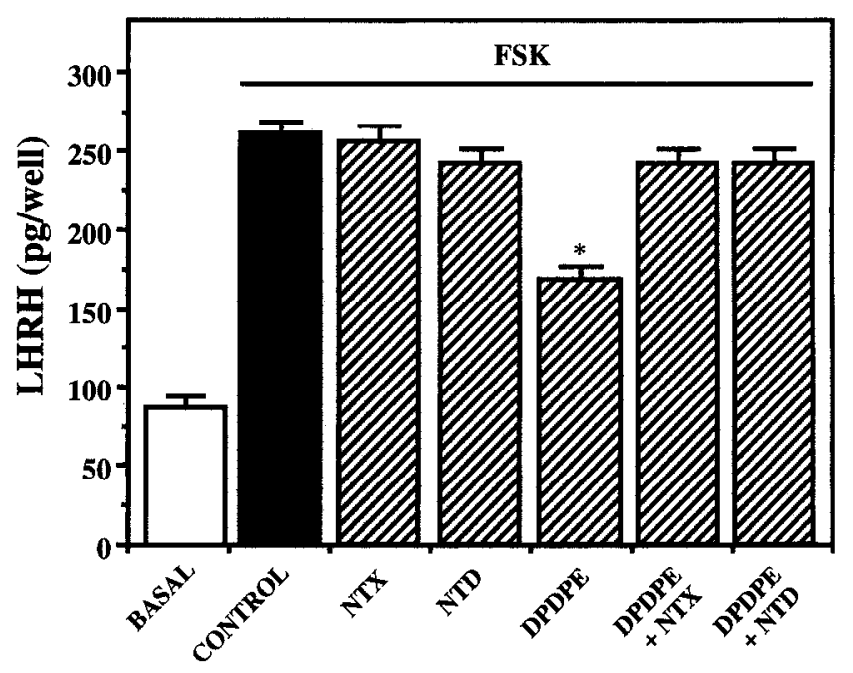

FIG. 4. Effects of the $\delta$-opioid agonist DPDPE and the opioid antagonists naltrexone (NTX) and naltrindole (NTD) on FSK-stimulated secretion of LHRH from GT1-1 cells. Cells were cultured with FSK $(5 \mu \mathrm{M})$ alone (CONTROL) or in combination with $1 \mu \mathrm{M}$ of the opioid antagonists and the opioid agonist DPDPE. Data represent the mean \pm SEM of sextuplicate samples. ${ }^{*}, P<0.05$ vs. control.

TABLE 2. Effects of DPDPE on the PGE ${ }_{2}$ and $P G_{1}$-stimulated release of LHRH from GT1-1 cells

\begin{tabular}{lc}
\hline \multicolumn{1}{c}{ Treatment } & LHRH $(\mathrm{pg} /$ well) \\
\hline Control & $91.6 \pm 7.0$ \\
PGE $_{2}$ & $220.8 \pm 17.9^{a}$ \\
PGE $_{2}+$ DPDPE & $175.9 \pm 16.6^{b}$ \\
PGE $_{1}$ & $252.8 \pm 26.8^{a}$ \\
PGE $_{1}+$ DPDPE & $167.2 \pm 13.5^{c}$ \\
\hline
\end{tabular}

Cells were incubated with $\mathrm{PGE}_{2}(10 \mu \mathrm{M})$ or $\mathrm{PGE}_{1}(1 \mu \mathrm{M})$ alone or in combination with DPDPE $(1 \mu \mathrm{M})$. Data represent the mean \pm SEM of sextuplicate samples.

${ }^{a} P<0.05$ vs. control.

${ }^{b} P<0.05$ us. $\mathrm{PGE}_{2}$.

${ }^{c} P<0.05$ vs. $\mathrm{PGE}_{1}$.

of LHRH from GT1-1 neuronal cells when these are stimulated by FSK or PGs $\left(\mathrm{PGE}_{2}\right.$ and $\left.\mathrm{PGE}_{1}\right)$. The effect is dose related and appears to be due to a specific receptorial mechanism, as it was eliminated by simultaneous treatment with either the universal antagonist naltrexone or the specific $\delta$-receptor antagonist naltrindole. These antagonists given alone did not exert any effect on LHRH-stimulated release. An inhibitory effect on LHRH release was also obtained when DADI.E (a mixed $\delta / \mu$-agonist) (23) was added to the FSKstimulated GT1-1 cells; in the authors' opinion, this effect is due to the interaction of this enkephalin analog with $\delta$-receptors, as these are the only ones present on GT1-1 cells (18); this assumption is reinforced by the fact that morphine, the specific $\mu$-receptor agonist DAGO, and the specific $\kappa$-agonist U50488H are ineffective in stimulated conditions.

It is interesting to note that none of the opioid agonists (DAGO, DPDPE, DADLE, and U50488H) or antagonists (naltrindole and naltrexone) tested was able to modify LHRH release from GT1-1 cells in the absence of LHRH-activating stimuli (e.g. FSK and PGs); this observation underlines the fact that the effect of opioids in GT1-1 cells is predominantly inhibitory, and that the inhibitory effect exerted by opioids 
on I.HRH secretion in vivo $(16,24)$ is in reality due to the fact that opioids eliminate stimulatory inputs impinging on hypothalamic LHRH-producing neurons (2). In addition, the lack of effect of the opioid antagonists in GT1-1 cells, when given alone, suggests that endogenous opioids are not synthesized in these cells.

The inhibition of LHRH secretion from GT1-1 cells induced by DPDPE is dose dependent and characterized by an $\mathrm{IC}_{50}(17 \mathrm{nM})$ very close to their $\mathrm{K}_{\mathrm{x}}$ value $(14.5 \mathrm{nM})$ in competing for the binding of $\left[{ }^{3} \mathrm{H}\right]$ diprenorphine to intact GT1-1 cells (18).

Interestingly, DPDPE is effective in inhibiting not only the PG-induced release of LHRH (the present data) but also the accumulation of cAMP induced by these factors (18). These results and those reported here showing that DPDPE inhibits LHRH release stimulated by the potent adenylyl cyclase activator FSK suggest that the inhibitory effect of DPDPE on LHRH release from GT1-1 cells is mediated by a classical mechanism of action of the opioids, namely the inhibition of cAMP formation (20).

It has been recently reported that $\delta$-opioid receptors may be subdivided into two subclasses, named $\delta_{1}$ and $\delta_{2}$, on the basis of the in vivo effects of different putative $\delta$-agonists (25, 26). In fact, $\delta_{1}$-receptors appear to be preferentially activated by DPDPE, while $\delta_{2}$-receptors are specifically stimulated by $\left[\mathrm{D}-\mathrm{Ala}^{2}\right]$ deltorphin II and DSLET $(26,27)$. Consequently, the question may be asked whether GT1-1 cells functionally possess both subtypes of receptors. The present authors have several lines of evidence suggesting that the effects reported may be explained by the presence of only the $\delta_{1}$-subclass of receptors. In fact, the binding experiments previously reported on GT1-1 cells have shown the existence of a single independent class of opioid receptors (18). Displacement studies using DPDPE in a wide range of doses (up to those that should activate $\delta_{2}$-receptors) also revealed the interaction with a single class of sites, with a $K_{r}$ very close to the reported affinity of DPDPE on the $\delta_{1}$-site (28). In line with previous observations, in the present experiments the doseresponse curve of the inhibitory effect exerted by DPDPE on LHRH secretion is characterized by a slope not significantly different from unity, indicating a simple interaction with a single class of binding sites. In addition, DADLE, which binds $\delta_{1}$ - and $\delta_{2}$-receptors with equal affinity (28), has not shown a potency different from that of DPDPE, as would have been expected if activation of the two types of receptors had occurred (27).

In a recent report, Nazian et al. (29) showed that a single $10-\mu \mathrm{M}$ concentration of morphine suppresses the LHRH response to isoproterenol and dopamine in perfused GT1-7 cells; these data underline once more a possible direct inhibitory effect of opioids on LHRH-secreting cells and suggest that this appears only after stimulation by secretagogues. In general, these results are in agreement with the data reported here. Nevertheless, the study by Nazian et al. (29) shows an apparent discrepancy with the results of the present study, as it shows an inhibitory effect of morphine (a preferential $\mu$-agonist), which was not found in the present study. It must be noted, first, that Nazian and co-workers (29) used an elevated dose of morphine, which may have bound not only to the $\mu$-receptors but also to $\delta$-binding sites (23).
Second, apart from the methodological differences that characterize the two studies (different clones of cells, static culture os. perfusion experiments, preincubation vs. acute treatment), Nazian et al. (29), at variance with other reports (18), have not characterized the type of opioid receptors present on GT1-7 cells.

More recently, Lagrange et al. (30) reported that the selective $\mu$-agonist DAGO hyperpolarizes some hypothalamic LHRH neurons in a direct fashion, suggesting the presence of $\mu$-opioid receptors on these cells. Again, this evidence supports a direct role of opioids in the control of LHRH secretion, but appears in contrast with the data reported here. However, it is clear that Lagrange et al. (30) studied a limited number of LHRH neurons; moreover, their experiments were performed in guinea pigs, whereas GT1-1 cells are a clonal cell population derived from the mouse. Consequently, the possibility cannot be discarded that Lagrange $e$ t al. (30) examined a subpopulation of LHRH neurons that might also possess $\mu$-receptors.

If one assumes that GT1 cells represent a good model for the study of LHRH-secreting neurons, the obvious conclusion from the data reported here is that endogenous opioid peptides may influence LHRH secretion by acting directly on LHRH-secreting neurons. A second conclusion would be that this effect of the opioids is mediated by the $\delta$-subclass of receptors. Obviously, it must be pointed out that the present data do not exclude that opioids might act in vivo on LHRH release via other mechanisms as well. As mentioned in the introduction, a large body of evidence implicates opioid peptides in the central mechanisms controlling LHRH secretion $(1,2,13,15-17)$. The prevailing theory proposes that opioid neurons have synaptic contacts with intermediate neurons, which, in turn, influence the secretion of LHRH via the release of their respective neurotransmitters (2). In contradistinction with the present data, which show the participation of $\delta$-receptors in the control of LHRH release from LHRH-producing neurons, a number of data obtained in vivo, especially in the rat, support the view that opioids affect LHRH release mainly through interaction with receptors of the $\mu$-type $(24,31)$. However, a few studies have also implicated $\delta$-receptors $(32,33)$ as well as $\kappa$-receptors $(32)$ in such a mechanism. For instance, Leadem and Yagenova (32) showed that $\delta$-agonists, including DPDPE, when given intraventricularly exert a biphasic effect on LH secretion in ovariectomized rats, and Gerozissis et al. (33) reported an inhibitory effect of the $\delta$-agonist DTLET on LHRH secretion from isolated rat hypothalamic fragments.

In conclusion, the data presented here, when analyzed in conjunction with the evidence previously available, may allow the hypothesis that the effects of endogenous opioid peptides on LHRH secretion consist of two distinct components: the first acting directly on the $\delta$-receptors present on LHRH-synthesizing neurons, and the second acting via intermediate neurons, where opioids probably interact mainly with the $\mu$-receptor subfamily.

\section{Acknowledgment}

The authors dedicate this work to Prof. Bela Flerkó (Pecs, Hungary) on the happy occasion of his 70 th birthday. 


\section{References}

1. McCann SM 1991 Neuroregulatory peptides. In: Motta M (eds) Brain Endocrinology. Raven Press, New York, vol 2, pp 1-30

2. Kalra SP 1993 Mandatory neuropeptide-steroid signaling for the preovulatory luteinizing hormone-releasing hormone discharge. Endocr Rev 14:507-538

3. Weiner RI, Findell PR, Kordon C 1987 Role of classic and peptide neuromediators in the neuroendocrine regulation of $\mathrm{LH}$ and prolactin. In: Knobil E, Neill JD (eds) The Physiology of Reproduction. Raven Press, New York, vol 1, pp 1235-1281

4. Mellon PL, Windle JJ, Goldsmith PC, Padula CA, Roberts JL, Weiner RI 1990 Immortalization of hypothalamic GnRH neurons by genetically targeted tumorigenesis. Neuron 5:1-10

5. Liposits Z, Merchenthaler I, Wetsel WC, Reid JAJ, Mellon PL, Weiner RI, Negro-Vilar A 1991 Morphological characterization of immortalized hypothalamic neurons synthesizing luteinizing hormone-releasing hormone. Endocrinology 129:1575-1583

6. Weiner RI, Wetsel W, Goldsmith P, Martinez de la Escalera G, Windle J, Padula C, Choi A, Negro-Vilar A, Mellon P 1992 Gonadotropin-releasing hormone neuronal cell lines. Front Neuroendocrinol 13:95-119

7. Martinez de la Escalera G, Choi ALH, Weiner RI 1992 ß1-Adrenergic regulation of the GT1 gonadotropin-releasing hormone (GnRH) neuronal cell lines: stimulation of GNRH release via receptors positively coupled to adenylate cyclase. Endocrinology 131: 1397-1402

8. Martinez de la Escalera G, Gallo F, Choi ALH, Weiner RI 1992 Dopaminergic regulation of the GT1 gonadotropin-releasing hormone (GnRH) neuronal cell lines: stimulation of $\mathrm{GnRH}$ release via D1-receptors positively coupled to adenylate cyclase. Endocrinology 131:2965-2971

9. Hales TG, Kim H, Longoni B, Olsen RW, Tobin AJ 1992 Immortalized hypothalamic GT1-7 neurons express functional $\gamma$-aminobutyric acid type A receptors. Mol Pharmacol 42:197-202

10. Urbanski HF, Fahy MM, Daschel M, Meshul C 1994 N-Methyl-Daspartate receptor gene expression in the hamster hypothalamus and in immortalized luteinizing hormone-releasing hormone neurones. J Reprod Fertil 100:5-9

11. Mahachoklertwattana P, Sanchez J, Kaplan SL, Grumbach MM $1994 N$-Methyl-D-aspartate (NMDA) receptors mediate the release of gonadotropin-releasing hormone $(\mathrm{GnRH})$ by NMDA in a hypothalamic GnRH neuronal cell line (GT1-1). Endocrinology 134:10231030

12. Moretto M, Lopez FJ, Negro-Vilar A 1993 Endothelin-3 stimulates luteinizing hormone-releasing hormone (LHRH) secretion from LHRH neurons by a prostaglandin-dependent mechanism. Endocrinology 132:789-794

13. Meites J, Bruni JF, Van Vugt DA, Smith AF 1979 Relation of endogenous opioid peptides and morphine to neuroendocrine function. Life Sci 24:1325-1336

14. Motta M, Martini L 1982 Effect of opioid peptides on gonadotrophin secretion. Acta Endocrinol (Copenh) 99:321-326

15. Martini L, Dondi D, Limonta P, Maggi R, Piva F 1989 Modulation by sex steroids of brain opioid receptors: implications for the control of gonadotropins and prolactin secretion. J Steroid Biochem 33: 673-681

16. Piva F, Maggi R, Limonta P, Motta M, Martini L 1985 Effect of naloxone on luteinizing hormone, follicle-stimulating hormone and prolactin secretion in the different phases of the estrus cycle. Endocrinology 117:766-772

17. Piva F, Limonta P, Maggi R, Martini L 1986 Stimulatory and inhibitory effects of the opioids on gonadotropin secretion. Neuroendocrinology 42:504-512

18. Maggi R, Pimpinelli F, Martini L, Piva F 1995 Characterization of functional opioid delta receptors in a luteinizing hormone-releasing hormone producing neuronal cell line. Endocrinology 136:289-295

19. Wetsel WC, Eraly SA, Whyte DB, Mellon PL 1993 Regulation of gonadotropin-releasing hormone by protein kinase- $\mathrm{A}$ and $-\mathrm{C}$ in immortalized hypothalamic neurons. Endocrinology 132:2360-2370

20. Leslie FM 1987 Methods used for the study of opioid receptors. Pharmacol Rev 39:197-249

21. Bradford MM 1976 A rapid and sensitive method for the quantification of microgram quantities of protein utilizing the principle of protein-dye binding. Anal Biochem 72:248-254

22. De Lean A, Munson PJ, Rodbard D 1978 Simultaneous analysis of families of sigmoidal curves: application to bioassay, radioligand assay, and physiological dose-response curves. Am J Physiol 235: E97-E102

23. Pasternak GW, Wood PJ 1986 Multiple mu opiate receptors. Life Sci 38:1889-1898

24. Panerai AE, Petraglia F, Sacerdote P, Genazzani AR 1985 Mainly $\mu$-opiate receptors are involved in luteinizing hormone and prolactin secretion. Endocrinology 117:1096-1099

25. Jiang Q, Takemori AE, Sultana $M$, Portoghese PS, Bowen WD, Mosberg HI, Porreca F 1991 Differential antagonism of opioid delta antinociception by $\left[\mathrm{D}-\mathrm{Ala}^{2}, \mathrm{Leu}^{5}, \mathrm{Cys}^{6}\right]$ enkephalin and naltrindole $5^{\prime}$ isothiocyanate: evidence for delta receptor subtypes. J Pharmacol Exp Ther 257:1069-1075

26. Traynor JR, Elliott J $1993 \delta$-Opioid receptor subtypes and cross-talk with $\mu$-receptors. Trends Pharmacol Sci 14:84-86

27. Buzas B, Izenwasser S, Portoghese PS, Cox BM 1994 Evidence for delta opioid receptor subtype regulating adenylyl cyclase activity in rat brain. Life Sci 54:PL101-PL106

28. Xu H, Ni Q, Jacobson AE, Rice KC, Rothman RB 1991 Preliminary ligan binding data for subtypes of the delta opioid receptor in rat brain membranes. Life Sci 49:PL141-PL146

29. Nazian SJ, Landon CS, Muffly KE, Cameron DF 1994 Opioid inhibition of adrenergic and dopaminergic but not serotoninergic stimulation of luteinizing hormone releasing hormone release from immortalized hypothalamic neurons. Mol Cell Neurosci 5:642-648

30. Lagrange AH, Ronnekleiv OK, Kelly MJ 1995 Estradiol-17 $\beta$ and $\mu$-opioid peptides rapidly hyperpolarize GnRII neurons: a cellular mechanism of negative feedback? Endocrinology 136:2341-2344

31. Pfeiffer DG, Pfeiffer A, Shimohigashi Y, Merriam GR, Loriaux DL 1983 Predominant involvement of mu- rather than delta- or kappaopiate receptors in LH secretion. Peptides 4:647-649

32. Leadem CA, Yagenova SV 1987 Effects of specific activation of mu-, delta- and kappa-opioid receptors on the secretion of luteinizing hormone and prolactin in ovariectomized rat. Neuroendocrinology 45:109-117

33. Gerozissis K, Dragatsis I, Zioudrou C 1993 The $\delta$-opioid signal transduction on the gonadotropin-releasing hormone release is $\mathrm{ei}$ cosanoid dependent. Brain Res 626:219-224 